\title{
Leptin, resistin and visfatin: the missing link between endocrine metabolic disorders and immunity
}

Ebtesam A AL-Suhaimi ${ }^{{ }^{*}+}$ and Adeeb Shehzad ${ }^{2^{*+}}$

\begin{abstract}
Adipose tissue is still regarded as a principle site for lipid storage and mobilizing tissue with an important role in the control of energy homeostasis. Additionally, adipose tissue-secreted hormones such as leptin, visfatin, resistin, apelin, omentin, sex steroids, and various growth factors are now regarded as a functional part of the endocrine system. These hormones also play an important role in the immune system. Several in vitro and in vivo studies have suggested the complex role of adipocyte-derived hormones in immune system and inflammation. Adipokines mediate beneficial and detrimental effects in immunity and inflammation. Many of these adipocytokines have a physiological role in metabolism. The uncontrolled secretions of several adipocytokines were associated with the stimulation of inflammatory processes leading to metabolic disorders including obesity, atherosclerosis, insulin resistance and type 2 diabetes. Obesity leads to the dysfunction of adipocytes andcorrelated with the imbalance of adipokines levels. In obese and diabetic conditions, leptin deficiency inhibited the Jak/Stat3/PI3K and insulin pathways. In this review, ample evidence exists to support the recognition of the adipocyte's role in various tissues and pathologies. New integral insights may add dimensions to translate any potential agents into the future clinical armamentarium of chronic endocrine metabolic and inflammatory diseases. Functional balance of both adipocytes and immune cells is important to exert their effects on endocrine metabolic disorders; furthermore, adipose tissue should be renamed not only as a functional part of the endocrine system but also as a new part of the immune system.
\end{abstract}

Keywords: Adipocytokines, Obesity, Diabetes, Endocrine, Immunity

\section{Review Introduction}

Adipose tissue is a complex network of endocrine organs that has been divided into white adipose tissue (WAT) and brown adipose tissue (BAT). WAT is mainly responsible for the insulation and mechanical support along with the energy storage function in the body, while BAT specializes in thermogenesis and lipid oxidation [1]. Activation of BAT also regulates channel efficiency to undertake triglyceriderich lipoprotein (TRL) clearance, as well as to prevent excess accumulation of lipids in the blood [1].

\footnotetext{
* Correspondence: Ealsuhaimi@ud.edu.sa; adeeb.shehzad@gmail.com ${ }^{\dagger}$ Equal contributors

'Department of Biology, Sciences College, University of Dammam, Dammam, Saudi Arabia

${ }^{2}$ School of Life Sciences, College of Natural Sciences, Kyungpook National University, Daegu 702-701, South Korea
}

The most abundant depots are visceral and subcutaneous adipose tissues, which produce unique profiles of adipokines [2]. These molecules are orchestrated by a multifarious network belonging to different functional categories such as immunity (complement factors, haptoglobulin), endocrine function (leptin, adiponectin, visfatin, resistin, apelin, omentin, sex steroids, various growth factors), metabolic function (fatty acids, adiponectin, resistin, vaspin), cardiovascular function (angiotensinogen), fatty acid, and prostaglandins [3-7].

Adipose tissue secretes many biologically active adipokines with diverse functions [3]. Adipokines are pharmacologically active, low molecular weight proteins that exert pleiotropic functions through several metabolic pathways [8]. Around the turn of the $20^{\text {th }}$ century several molecular mechanisms shed light on the importance of adipokines in the human system. To date, more than 20 different hormones (both orexigenic and anorexigenic) have been identified.

\section{Biomed Central}


Adipokines are important due to their crucial mediator role and active participation in metabolic functions. These hormones also easily cross the blood-brain barrier, reach the main site of action located in the hypothalamic region, exert their actions and mediate the balance of satiety and hunger. The adipokines have a central role in the control of energy metabolism, communicating the nutrient status of the organism including energy intake and expenditure as well as insulin sensitivity [9].

Adipokines have several mediators such as adiponectin, pre-B cell colony-enhancing factor (PBEF) visfatin, leptin, resistin and retinol-binding protein-4. Adiponectin is an intriguing adipokine with its serum level inversely correlated with fatness. It is related to the enhancement of insulin sensitivity, anti-inflammatory effects, anti-atherogenic actions, and regulation of metabolic homeostasis [10]. Recent investigations have also emphasized the importance of adipocytokines such as interleukin-6 (IL-6), tumor necrosis factor $\alpha$ (TNF $\alpha)$, plasminogen activator inhibitor-1, or a chemokine, and monocyte chemoattractant protein-1 (MCP-1). Nuclear factor-kappa B (NF-kB) is a transcription factor that has the potential to mediate immunity, stress, apoptosis, cytokines expression, inducible nitric oxide synthase (iNOS), cyclo-oxygenase 2 (COX-2), cell growth factors, and development, as well as the potential to play an important role in central nervous system and cell signaling. It is also known that NF- $\mathrm{BB}$ induces overexpression of transcriptional systems, which activate inflammation and develop cancer. NF- $\mathrm{kB}$ pathway inhibitors may be a useful therapeutic strategy to treat inflammation and cancer. Several studies have shown that lipid accumulation in the liver leads to hepatic inflammation through NF-kB activation and downstream cytokine production, which leads to insulin resistance hepatically, as well as systemically $[11,12]$. Some of the adipokines hormones such as leptin, adiponectin, resistin, and ghrelin play a role in the regulation of glucose metabolism and are involved in the development of obesity, diabetes, inflammation, auto-immunity and metabolic syndromes [13].

The current review summarizes the recent knowledge regarding the malfunction of adipokines such as leptin, resistin, and visfatin in the initiation and progression of many metabolic diseases including obesity, diabetes and immunity.

\section{Physiological and pro-inflammatory roles of adipokines}

The physiological, metabolic and pro-inflammatory role of different adipokines, such as, leptin, resistin, visfatin will be discussed individually and according to the role each plays in diabetes, obesity, and immunity.

\section{Leptin}

The discovery of leptin has led to a new era in nutrition biology. Leptin was discovered in mice in 1994 by Jeffrey
M. Friedman. Leptin is derived from the Greek word leptos, which means 'thin'. The serum concentration of leptin is predominantly defined by body fat mass [14] Leptin was the first identified adipocytokine, its primary structure is composed of 167 amino acids, and it is primarily expressed in adipose tissue. Leptin regulates energy homeostasis and interferes with several neuroendocrine and immune functions [15]. A higher amount of leptin is secreted by subcutaneous adipocytes than by the visceral adipocytes. Its presence has also been detected in many other tissues, including the placenta, mammary glands, breast milk, testes, ovaries, endometrium, stomach, hypothalamus, and pituitary gland [16]. Leptin is generally synthesized and secreted by gastric chief cells in the stomach [17]. Leptin circulating levels are directly proportional to the body fat. These levels range from 5 to $10 \mathrm{ng} / \mathrm{ml}$ in healthy individuals to 40 to $100 \mathrm{ng} / \mathrm{ml}$ in obese individuals [18]. A transient increase occurs during a meal, whereas leptin levels decrease with fasting, evoking a profound changes in energy balance and hormone levels [4,19,20].

The adipose tissue secretes specific proteins including leptin into the blood stream, which controls body weight by regulating metabolic behavior. It has a fundamental role in the control of appetite and also in regulating energy expenditures [21]. Leptin exerts pleiotropic effects by binding and activating specific leptin receptors (obR) in the hypothalamus and other organs. It has direct and indirect effects in metabolically active tissues and regulates several neuroendocrine axes [22,23]. So far, six different isoforms of leptin have been identified with diverse biological actions that range from affecting blood pressure to affecting immune functions [24,25]. Leptin receptors such as ObRa and ObRb are present in the brain and regulate metabolic behaviors [26]. Among leptin receptors, mRNA expression of the long form, ObRb, has been detected in the arcuate (ARC), dorsomedial $(\mathrm{DMH})$, ventromedial $(\mathrm{VMH})$, and ventral premamillary nuclei (PMV); moderate expression has been found in the periventricular hypothalamic nucleus, in the lateral hypothalamic area (LHA), and at lower levels of expression in the paraventricular nucleus (PVH) [27]. Early research was focused on leptin and its receptors in the hypothalamus region and leptin was believed to be an important regulatory hormone for signaling body fat status. However, it has become apparent that leptin receptors are expressed in many normal cell types throughout the body as well as in malignant cells. It is noted that the addition of leptin to cells in culture was found to promote proliferation and to inhibit apoptosis [27-29]. Leptin has been implicated as a growth factor for its ability to stimulate angiogenesis in metastatic breast cancer hypoxic conditions [30]. Angiogenesis is also a crucial factor in determining obesity and its related complications [31]. 


\section{Resistin}

Resistin is another unique adipocyte-derived signaling cysteine-rich molecule made up of 114 amino acids, and was first identified in obese mice. The resistin-like molecule (RELM) gene family is an $\mathrm{N}$-terminal signal peptide. Resistin (FIZZ3), known as the resistin-like molecules RELM; RELM, $\alpha / F I Z Z ~ 1$, and RELM $\beta /$ FIZZ 2, is involved in various inflammatory processes [32-34]. In addition, human resistin has also been detected in tissues like placenta, skeletal muscle, small intestine, spleen, stomach, thymus, thyroid gland and uterus [35-37].

Resistin expression was greater in white adipose tissue than in brown adipose tissue [35]. The resistin in mice is expressed in white adipose tissue, whereas human resistin is expressed in adipose tissue at a lower level [38]. However, resistin is predominantly expressed in macrophages in humans. Resistin is thus named because of its resistance to the action of insulin. It has been observed that circulating resistin levels are increased in obese humans. It is considered a pro-inflammatory molecule, which also plays an important role in the pathogenesis of diabetes and its complications. The release of resistin is often stimulated by the inflammatory process, IL-6, hyperglycemia and hormones such as growth hormone and gonadal hormones [39].

\section{Visfatin}

Visfatin, also known as pre-B cell colony-enhancing factor (PBEF), is a highly conserved, $52-\mathrm{kDa}$ protein found in living species from bacteria to humans [40]. Visfatin is also called NAMPT because of its significant sequence and functional homology with nicotinamide phosphoribosyltransferase (NAm-PRTase), an enzyme involved in nicotinamide adeninedinucleotide (NAD) biosynthesis from nicotinamide [41]. It is produced by the visceral adipose tissue. The expression of visfatin is increased in individuals with abdominal obesity and type 2 diabetes [38].

\section{Leptin, resistin and visfatin and their relation to obesity Leptin and obesity}

In recent years a remarkable progress has been made in the understanding of obesity pathophysiology. The more recent findings have corroborated that leptin may signify a link between obesity and metabolic disorders [41]. In normal mice, the leptin interacts with the products of leptine receptor (Lepr) locus [42] in the choroid plexus [43]. It is postulated that leptin deficiency occurs in the genetically obese Lep $^{\text {ob }}$ mouse [44].

Genetically obese mice strains were discovered because of a mutation in the leptin receptor [42]. Lep ${ }^{\text {ob }}$ mouse have elevated levels of leptin in serum, which is the hallmark of the relationship between leptin and its positive association with body weight, body mass index (BMI), and fat mass
[45-47]. Diabetes $(\mathrm{db} / \mathrm{db})$ mice have a deletion in the long isoform of the leptin receptor; therefore, it is resistant to leptin [48]. Leptin circulates proportionally to adipocytes, regulating food intake and energy expenditure through the expression of ObRb receptors in the central nervous system (CNS) [49]. In addition, leptin binds to the neuropeptide neuron in the mediobasal hypothalamus and signals the brain regarding the adipose stores, producing appropriate conditions of satiety through neurotransmitters and other related hormones. Experimental studies have implicated leptin as a crucial controller of body weight through central and peripheral pathways [50] because circulating leptin conveys information to the hypothalamus regarding the amount of energy stored in adipose tissue; suppresses the appetite, affects energy expenditure [51], affects weight reduction; and significantly increases with the circulating levels of adiponectin. However, the two hormones perform complementary actions, and may have synergistic effects [52].

The long isoform of the leptin receptor $(\mathrm{Ob} \mathrm{Rb})$ is a vital activator of janus kinase signal transduction and translation/signal transducer and activator of transcription (JAK/ STAT) pathway [49]. It has been reported that the JAK/ STAT pathway is responsible for leptin regulation of energy homeostasis [53,54]. Suppressor of cytokine signaling 3 (SOCS-3) protein is a negative feedback regulator of leptin signaling involved in leptin resistance. The potential mechanism contributing to leptin resistance occurs through upregulation of SOCS-3 expression by inhibiting the signal transduction stage of leptin receptor $[55,56]$. The suppressor of cytokine signaling (SOCS) protein inhibits the JAKSTAT pathway and leads to leptin resistance and obesity [57]. In the hypothalamus the phosphatidylinositol 3-kinase (PI3K) pathway interaction with the JAK2/STAT3 cascade plays a significant role in the signal transducing leptin action [58]. In obese conditions the leptin resistance downregulates the Src/PI3K/Akt pathway [59]. Obstruction of the Jak/Stat3/PI3K-dependent pathways upregulates the effects of vascular endothelial growth factor (VEGF) to enhance angiogenesis in adipocytes [60-62]. In mice, such a disrupted JAK/STAT pathway results in an increased food intake and accumulation of adipose tissue [53]. Buettner et al. has reported that the restoration of STAT3 signaling is an effective therapy for leptin defective diseases [63]. In obese condition, leptin resistance is accompanied by hyperinsulinemia and insulin resistance [64] (Figure 1).

\section{Resistin and obesity}

Serum resistin was positively correlated with changes of BMI and body adipose mass. Circulating resistin levels increase with age, probably reflecting the increase in the body fat content [65]. With human obesity elevated serum resistin levels were observed when compared with humans in lean condition [66]. Resistin is involved in 


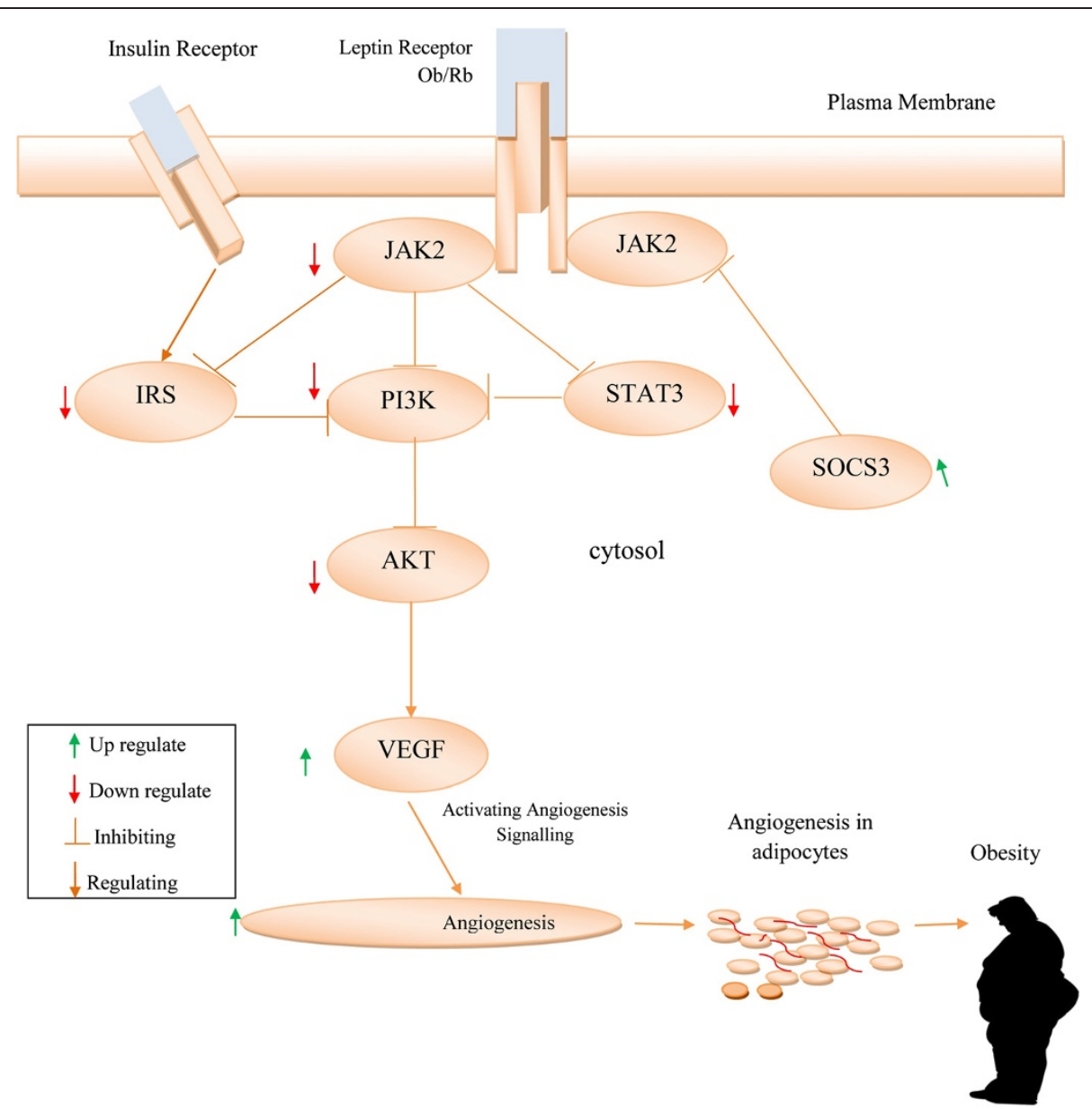

Figure 1 Obstruction of Jak/Stat3/PI3K-dependent pathways stimulated VEGF to stimulate angiogenesis in adipocytes thereby leading to obesity.

the proliferation of adiposities and angiogenesis [66-69]. Obesity is associated with abnormally elevated JNK activity, predominantly provided by JNK1. It is a vital component of the obesity-induced insulin resistance pathway in vivo [70]. Scientists have suggested that resistin is a hormone that links obesity to diabetes. Experiments in humans have shown no differences in resistin expression among normal, insulin-resistant, and type 2 diabetic samples. However, some recent genetic studies have demonstrated an association between resistin and insulin resistance and obesity [71]. Resistin has been shown to antagonize insulin action. Resistin levels are increased in diet-induced obesity as well as in genetic models of obesity and insulin resistance. Also, resistin gene expression is markedly down-regulated by treatment with anti-diabetic drugs called thiazolidinediones that improve target-tissue sensitivity to insulin. It was found that human abdominal adipose tissue has a higher amount of resistin mRNA than other fat depots [72]. Abdominal adipose tissue is thought to be a main risk factor for insulin resistance. It has also been reported that resistin is expressed in the hypothalamus and is able to activate hypothalamic neurons [73,74]. Another study showed that central administration of resistin resulted in increased number of cells expressing Fos (c-Fos is a protein encoded by the FOS gene) in the arcuate nucleus and promoted short-term satiety in rats [75].

\section{Visfatin and obesity}

Several studies have observed no difference in visfatin mRNA expression in visceral and subcutaneous adipose tissue in humans [75]. However, other studies confirmed an increased level of circulating visfatin whereas results from other studies were contradictory in that they showed lower levels of plasma visfatin in obese subjects [76-80]. It was also reported that overnutrition downregulated circulating visfatin concentrations in humans [81]. The controversial findings on visfatin levels as a result of obesity and metabolic syndrome, suggest that an increased [82], a decreased [83,84], or unchanged level of visfatin-induced endothelial angiogenesis occurs through mediating VEGF, MMP, MAPK and PI3K/Akt signaling pathways [85]. 


\section{The relation of leptin, resistin and visfatin with diabetes Leptin and diabetes}

Leptin deficiency not only leads to obesity, but also to diabetes and to reproductive dysfunction. An interruption of hepatic metabolism of glucose, fatty acids, and lipoproteins in the leptin-deficient obese $\left(\mathrm{Lep}^{\mathrm{ob} / \mathrm{ob}}\right)$ mouse leads to hyperglycemia, steatosis, and hypercholesterolemia [86]. Leptin and insulin levels are directly interconnected with body weight and adipose tissue [87]. Leptin has impressive effects on the energy homeostasis, including regulation of insulin secretion by pancreatic $\beta$ cells [88]. In the brain, insulin and leptin act to inhibit the appetite [89]. Leptin may also directly affect the metabolism and function of peripheral tissues. Leptin has been implicated in causing peripheral insulin resistance by attenuating insulin action, and perhaps insulin signaling, in various insulin-responsive cell types. Additionally, various researchers have demonstrated a significant relationship between leptin and insulin [90].

Insulin and leptin influence the glucose metabolism by acting at a peripheral and central level [91]. They act as adiposity signals and play a pivotal role in the central regulation of energy homeostasis [92]. Both hormones circulate at proportional levels to body fat and regulate food intake and energy expenditure by interacting with their respective receptors [93]. Levi et al. reported that leptin administration was able to increase plasma IGFBP-2 levels and improve glucose homeostasis in both ob/ob mouse models [94].

Early reports showed that insulin and leptin play a significant role in diabetic condition by activating the insulin receptor substrate (IRS)-PI3K pathway (Figure 2). Schultze et al. reported that the development of insulin resistance and T2DM occurs with stimulated PI3K and downregulation of IRS proteins [95]. Insulin acts by modulating glucose metabolism via the STAT3 permissive effect. Initiation of STAT3 is necessary for the P13K activation [96]. Akt is a critical central mediator that acts along with PI3K for insulin signaling [97]. In addition, PI3K and Akt involve in insulin-stimulated translocation of the glucose transporter type 4 (GLUT4) [98,99].

Under normal circumstances, GLUT4 is responsible for insulin-stimulated glucose uptake from circulation into skeletal muscle [100]. It is reported that GLUT4 levels are reduced in the muscle of Type 2 diabetic condition [101]. Glucose uptake is regulated by GLUT4 and retained by activated PI3K [102]. Glucose uptake into the cells is stimulated by insulin and leptin activating the JAK2/IRS/PI3K/AKT signaling pathway [103] and triggering the translocation of the GLUT4 from the cytosol to the cell surface [104] Downregulation of PI3K and $\mathrm{AKT}$ indicates an insufficiency of insulin to maintain the normal signaling [105] and downregulates the intake of glucose through GLUT4 in the muscles, which results in hyperglycemia [106]. Glycogen synthase kinase-3 (GSK-3) is a serine/threonine protein kinase that has multiple negative impacts in insulin-mediated metabolic diseases $[107,108]$. GSK-3 adversely affects the insulin role by hindering activation of glycogen synthase, leading to the accrual of glycogen in the muscle [109].

AMP-activated protein kinase (AMPK) is an imperative enzyme in leptin signaling related to PI3K pathway [110]. Both PI3K/AKT and AMPK are involved in regulating glucose homeostasis [95]. In normal condition, AMPK stimulates catabolism and impedes anabolic pathways. Leptin deficiencies decrease the AMPK activity in the liver but increase its activity in the hypothalamus of the diabetic rat, thereby resulting in diabetic hyperphagia [111]. In diabetic ob/ob mice, the insulin signaling pathways were deregulated, which are found to be reinstated by systematic leptin treatment [112].

Apart from the diabetes, leptin also affects a variety of other physiological functions, including fertility, bone metabolism, and immune responses [113].

\section{Resistin and diabetes}

The role of adipocyte hormones in modulating insulin sensitivity and glucose tolerance are of common interest and importance in studies of type 2 diabetes mellitus. Recently, resistin has been proposed to play an important role in the pathogenesis of obesity-related insulin resistance [114]. Previous studies have postulated the controversial role of resistin in obesity and insulin resistance. Some studies have shown a positive correlation with body fat mass and insulin resistance $[114,115]$, whereas others have found no correlation with body mass index (BMI) or insulin sensitivity [116,117]. Resistin is expressed in pre-adipocytes and adipocytes, which may promotes resistin elevation in the adipose tissue of obese human [117,118]. Resistin is produced primarily by adipose tissue and may act at sites distant from where it is produced. In humans, insulin resistances are positively correlated with expression of resistin [119]. In diabetic patients, serum levels of resistin are nearly $50 \mathrm{ng} / \mathrm{ml}$. Resistin increases insulin resistance with respect to carbohydrate metabolism [120].

An elevated expression of resistin in circulation leads to glucose intolerance, hyperinsulinemia related with impaired insulin signaling in skeletal muscle, liver, and adipose tissue. The important role of AMPK in the liver is to stimulate the fatty acid oxidation, thwart cholesterol synthesis and intonate insulin secretion by pancreatic $\beta$ cells. Resistin inhibits the phosphorylation of the hepatic AMPK pathway that downregulates $\beta$ oxidation to lipid accumulations [121]. Subsequently, resistin stimulates SOCS-3 in mice adipose [122]. The stimulated SOCS-3 inhibits the insulin signaling pathway in tissues. Moreover, resistin affects glycogen metabolism, leading to type 2 diabetes [123]. 


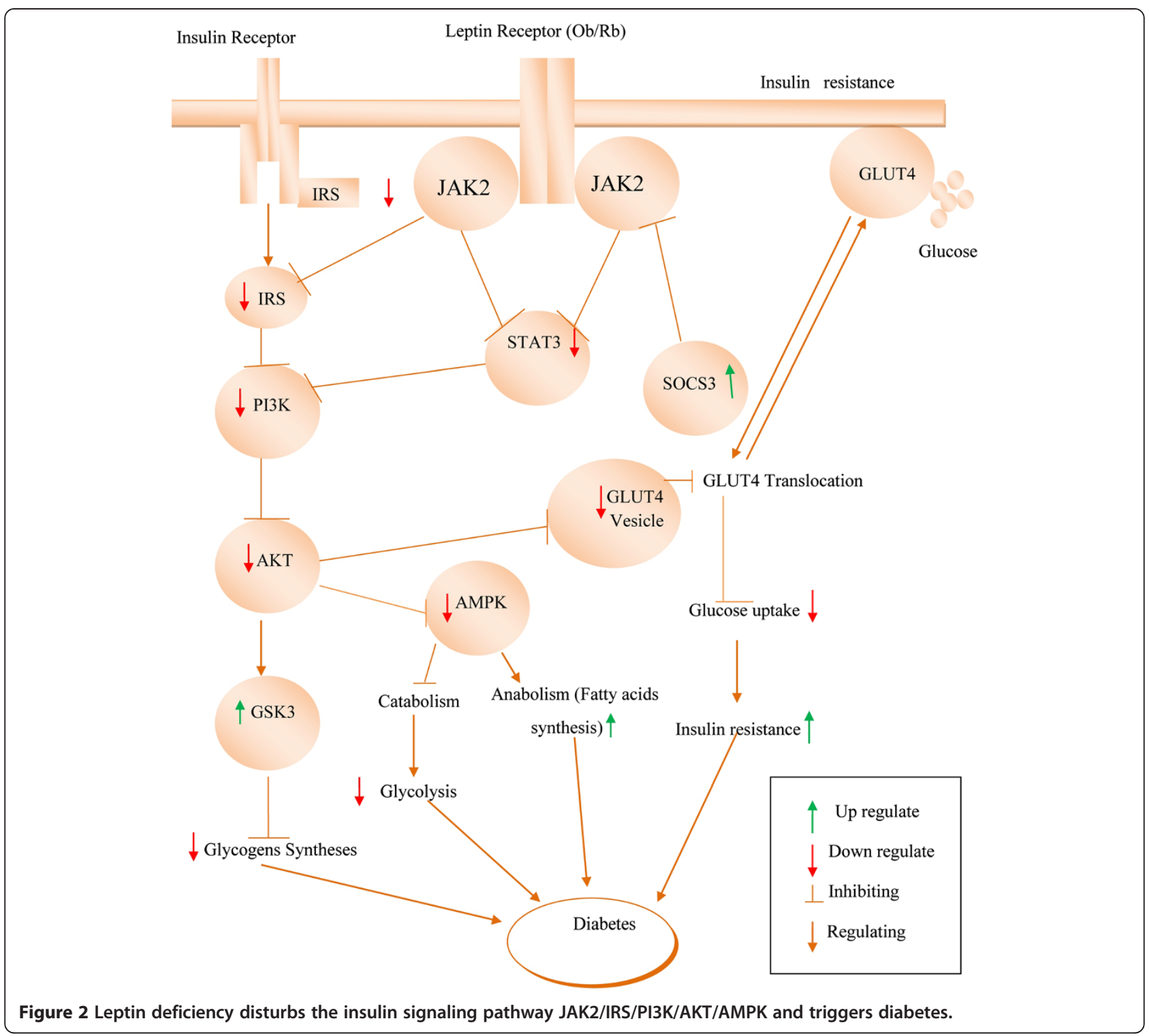

An elevated level of circulating resistin was detected in obesity and diabetes. This discovery suggests that deregulation of resistin induces insulin resistance in genetic models (ob/ob and $\mathrm{db} / \mathrm{db}$ ) and in a diet-induced model of diabetes and obesity. Studies have shown that loss of resistin in obesity decreases the blood glucose levels and improves insulin sensitivity [124]. Paradoxically, $\mathrm{db} / \mathrm{db}$ mice were not found with elevated levels of resistin when compared with the control group, nor has variation in resistin mRNA levels been reported in ob/ob mice. This means that some oversecretion of resistin from adipocytes may decrease the total number of resistin per cells, highlighting the tissue and cell-specific effect of resistin $[123,125]$. In humans, resistin is primarily released by monocytes/macrophages, suggesting that soluble levels may be associated with macrophage activation. Here, systemic and monocyte-released resistin levels were found to be similar in type 2 diabetic patients, overweight controls and normal-weight controls [126]. The aforementioned results strongly support the role of human resistin in the development of insulin resistance and inflammation. Thus, human resistin may be linked from insulin resistance to inflammatory diseases such as obesity, type 2 diabetes, and atherosclerosis [127].

\section{Visfatin and diabetes}

In adipokines, resistin is considered important for their pro-inflammatory effects. Alternatively, visfatin is known for insulin-mimetic/sensitizing effects. It is overexpressed in the route of adipocyte differentiation. Studies have shown that the synthesis and secretion of visfatin is modulated by glucocorticoids, TNF $\alpha$, IL-6, and growth factors. 
This means that visfatin is upregulated in the course of pro-inflammatory cytokines and under inflammatory conditions. Also, the findings of McGee et al. have suggested that visfatin may represent a pro-inflammatory cytokine that is influenced by insulin/insulin sensitivity via the NF- $\kappa$ B and JNK pathways [128].

The biological role of visfatin is not entirely understood, but several studies indicated glucose lowering and insulin-mimicking/-sensitizing effects of visfatin. Heterozygous mice with a target mutation in the visfatin gene had modestly higher levels of plasma glucose impaired glucose tolerance and reduced glucose-stimulated insulin secretion relative to control mice [128]. But there was no significant correlation of plasma visfatin levels and parameters of insulin sensitivity, including fasting insulin, fasting plasma glucose concentrations, and the glucose infusion rate during the steady state of a euglycemic hyperinsulinemic clamp independent of percent body fat. There are also conflicting data on visfatin circulating levels in obese humans.

\section{The relation of leptin, resistin and visfatin with immunity Leptin and immunity}

Leptin's role in immune responses has been recently reviewed. It modulates the monocytes/macrophages, neutrophils, basophils, eosinophils, natural killer and dendritic cells. Leptin modifies T-cell balance, induces $\mathrm{T}$-cell activation, and changes the pattern of T-cell cytokine production by driving $\mathrm{T}$-cell differentiation towards a T-helper1(TH1) response. This led to studies of the pro-inflammatory role of leptin in several animal models of autoimmune /inflammatory conditions. Studies have shown that leptin modulation in the immune system is mediated at development, proliferation, maturation and production levels [129]. However, the functional role of leptin is abrogated in the immune cells through the modulation of multiple signaling pathways, including STAT-3, PI3K, and P38 mitogen-activated protein kinase (MAPK) [130]. In fact, leptin and leptin receptors have pleiotropic effects in immune cells, promoting T-helper 1 responses, natural killer cell cytotoxicity, and production of inflammatory cytokines such as C-reactive protein (CRP), IL-6, TNF $\alpha$, and serum amyloid A [131]. It is believed that leptin is a pro-inflammatory adipokine that induces $\mathrm{T}$ helper 1 cells and may contribute to the development and progression of autoimmune responses [132]. Leptin receptor is also upregulated by aforementioned pro-inflammatory signals [133]. Results showed that peripheral rather than central leptin treatment was able to significantly increase numbers of granulocytes, Nutral Killer cells (NK) cells and monocytes [134]. Furthermore, it characterized NK cell differentiation and maturation in the bone marrow of leptin-receptor deficient $\mathrm{db} / \mathrm{db}$ mice at a prediabetic stage [135]. Leptin signaling regulates NK cell development via enhancing the survival of immature
NK cells in mouse bone marrow. A lot of compelling evidence has shown that leptin is the connection between nutritional status and immune competence. Leptin has been shown to regulate the immune responses in innate and adaptive response in normal and pathological conditions [134]. A study of adult leptin receptor-defective ( $\mathrm{db} / \mathrm{db})$ mice demonstrated a significant reduction of both NK cell numbers and NK cytotoxic capacity compared with wild-type mice. Treatment of NK (CD56+) cells with leptin enhanced CD69 expression and stimulated splenic NK cytotoxicity in wild-type mice, but not in $\mathrm{db} / \mathrm{db}$ mice. Furthermore, the decreased number of NK cells in the $\mathrm{db} / \mathrm{db}$ mice has confirmed the role of leptin in the maturation of NK cells [136]. On the other hand, leptinactivating pro-inflammatory cytokines such as IL-6 and TNF- $\alpha$ protect $\mathrm{Ob} / \mathrm{ob}$ mice from $\mathrm{T}$ cell hepatotoxicity [136]. Leptin mediate the inflammatory infiltrate and could act as a monocyte/ macrophage chemoattractant, inducing in vitro maximal chemotactic responses at $1 \mathrm{ng} / \mathrm{mL}$ [137] and inducing tissue-factor expression in human peripheral blood mononuclear cells [138]. Epidemiological observations indicated that reduced leptin production is closely associated with increased infection, which is the major cause of inflammatory or immunodeficiency diseases. Indeed, starvation or malnutrition is one of the human health concerns that increased the vulnerability to infections [132]. Conversely, immune-mediated disorders such as autoimmune diseases are associated with increased secretion of leptin and production of pro-inflammatory pathogenic cytokines. Thus, leptin is a mediator of the inflammatory response [139]. Furthermore, leptin treatment directly affects the lymphocytes and increases the differentiation and proliferation of CD4+ T cells [140].

Leptin appears to modulate $\mathrm{TH}$ cells and leading to stimulate TH1 production of some cytokines: interleukin 2 IL-2, interferon gamma (IFN- $\gamma$ ), TNF- $\alpha$ and IL-18, and inhibits the production of TH2 cytokines: IL-4, IL-5 and IL-10 [140], But T lymphocytes from $\mathrm{db} / \mathrm{db}$ mice do not show the same result, which supports the idea of the direct effect involving the expression of leptin receptors on the T lymphocytes [141]. Currently, leptin replacement therapy enhanced $\mathrm{T}$-cell responsiveness and inducing T-helper 1 cells and may contribute to the development and progression of autoimmune responses [132]. Modifications in the relative proportions of the lymphocyte classes depend on the degree of obesity, or on leptin concentration, or even fat depot anatomical location. It is suggested that alterations in the number and composition of lymphocytes precede an increase in macrophages and enhance the inflammatory state of WAT found in obesity. Lymphocytes express receptors to adipokines while several pro-inflammatory chemokines are produced in WAT, rendering intricate crosstalk between fat and immune cells [142]. 


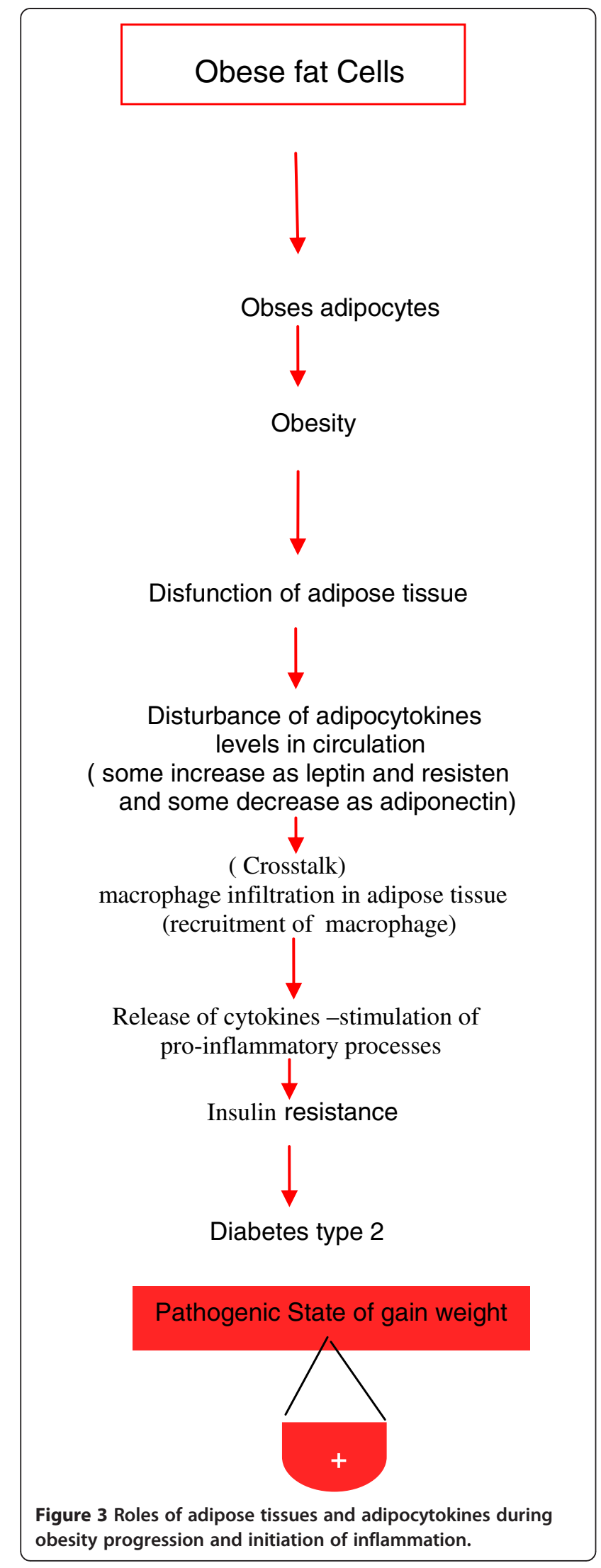

\section{Resistin and immunity}

More recently, it was found that high resistin levels predicted favorable anti-inflammatory effects of inhaled glucocorticoids suggesting that resistin may be a marker of a steroid-sensitive phenotype in asthma [143]. Resistin might contribute to the inflammatory conditions by mediating enhanced activation of cytokines (IL-6, TNF $\alpha$ ) and NF-kB [124]. Analyses of resistin gene expression across a wide array of human tissues revealed that peripheral blood mononuclear cells (PBMCs), macrophages and bone marrow cells are the major sources of human resistin $[36,144]$. Several studies demonstrated that inflammatory stimuli mediate resistin production. In human PBMCs, pro-inflammatory cytokines such as IL-1, IL-6 and TNF- $\alpha$, as well as Lipopolysaccharides (LPS), have strongly induced resistin mRNA expression [144]. Resistin significantly enhanced the hepatic inflammation and necrosis in LPS-induced liver damage in mice. This effect of resistin was presumably mediated via activation mechanisms involving the coagulation cascade and fibrin accumulation [145]. Resistin is likely to play an important role in chronic inflammatory and autoimmune diseases [146]. An increased level of circulating resistin was also observed in patients with chronic pancreatitis, suggesting its impact on pancreatic fibrosis development [147]. However, circulating resistin levels were clearly associated with general inflammation, renal disease, treatment with glucocorticoids, and bone loss in systemic lupus erythematosus patients [148].

\section{Visfatin and immunity}

Visfatin is not only an adipocyte-specific protein; its expression gene was originally found in human peripheral blood lymphocytes. It increases the effect of IL-7 and stem-cell factor on pre-B cell colony formation [149]. Visfatin appears to be an important mediator of inflammation. It is demonstrated that recombinant visfatin induced dose-dependent production of pro-inflammatory IL- $1 \beta$, TNF- $\alpha$, and IL- 6 as well as anti-inflammatory cytokines like IL-10, and IL-1 receptor antagonist in human monocytes. In vivo intraperitoneal injections of recombinant murine visfatin significantly increased circulating IL-6 levels and IL-6 mRNA expression in the small intestine in mice [150]. Other studies demonstrated that visfatin was also synthesized and released by neutrophils in response to inflammatory stimuli and that it functioned as an inhibitor of apoptosis resulting from variety of inflammatory stimuli. Visfatin was expressed at high levels in neutrophils harvested from septic critically ill patients and contributed to prolonged neutrophil survival in clinical sepsis [151]. The physiology of visfatin revealed that it is upregulated in the acute lung injury and sepsis as well as in inflammatory bowel disease [152]. 
General physiological functions of leptin and other adipocytokines are important in mediating the physiological role of adipose tissue in different models. Either adipocytes or immune cells and their secretory and metabolic activities should be taken under consideration (Figures 3) [11]. Therefore, immunotherapy deserves to be considered as a promising approach to treat the endocrinometabolic disorders associated with excessive fat mass development.

Important advances in our understanding of the relationships among adipokinesmetabolism and the immune response have been clarified in the past 10 years. White adipose tissue has served as a highly active organ that releases a plethora of immune and inflammatory mediators that are involved in many diseases [153].

\section{Future prospects}

Several in vitro and in vivo experiments have confirmed that adipokines have numerous important functions in the body. Research in this area is increasing and tremendous efforts have been made in exploring the physiological mechanisms of adipokines action in metabolic disorders andinflammatory autoimmune disorders. The exact mechanisms and the roles of adipokines remain hazy, and future research will further underpin the potential prospects for therapeutic action.

Much compelling evidence has shown the promotion of inflammation by elevating levels of leptin and resistin. It is conceivable that control of circulating levels of leptin and resistin might prevent inflammatory diseases. Leptin receptor could be stopped from activation with antibodies or legend This means the energy intake role of leptin should not be perturbed because development of hyperphagia and obesity might occur. At present, different studies are underway that are designed to gain insights into the known adipokines, their genetic bases and the cellular events that are taking place in the promotion of inflammatory ailments through the modulation of the adipokines. However, many questions need to be addressed before adipokines can be used as therapeutic targets in inflammatory complications. The depth of the mechanism and the signaling pathways of adipokines presented here are still incomplete and need future attention to elaborate the specific role of each adipokine. Nevertheless, studies that are able to clarify the role of adipokines in the different models, may demonstrate that these adipokines can indeed be essential targets for pharmacotherapeutic agents for the treatment of obesity-induced inflammatory diseases.

\section{Conclusions}

Physiological functions of adipocytokines and cytokines have principle roles in different styles and tissues. Adipokines (leptin, resistin and visfatin) could serve as a missing link in the causal relationship between psoriasis and comorbidities and may provide a biomarker for disease severity such as obesity and diabetes, risk of comorbidities and treatment success. Additionally, adipocytokines have numerous anti-inflammatory actions. Visfatin also mimics insulin effects. The functional balance of adipocytes and immune cells that is needed for them to exert their metabolic activities should be taken under consideration. Development of novel therapeutic procedures for obesity and obesity-associated diseases possibly could be achieved through an integral insight into leptin, resistin and visfatin, as well as insight into other adipokine functions and their links to inflammation.

\section{Abbreviations \\ AMPK: AMP-activated protein kinase; ARC: Arcuate nucleus; BAT: Brown adipose tissue; BMI: Body mass index; CNS: Central nervous system; COX-2: Cyclo-oxygenase 2; DMH: Dorsomedial nucleus; GSK-3: Glycogen synthase kinase-3; IL-6: Interleukin-6; iNOS: Inducible nitric oxide synthase; IRS: Insulin receptor substrate; LHA: Lateral hypothalamic area; LPS: Lipopolysaccharides; MAPK: Mitogen-activated protein kinase; MCP-1: Monocyte chemoattractant protein-1; NF-kB: Nuclear factor-kappa B; PMBCs: Peripheral blood mononuclear cells; PMV: Ventral premamillary nucleus; PVH: Paraventricular nucleus; RELM: Resistin-like molecule; TH: T-helper; TNFa: Tumor necrosis factor a; TRL: Triglyceride-rich lipoproteins; VEGF: Vascular endothelial growth factor; VMH: Ventromedial nucleus; WAT: White adipose tissue.}

\section{Competing interests}

The authors declare no competing interests.

\section{Authors' contributions}

EAA-S designed, drafted the manuscript and draw the figures. AS added new sections, rewrite another and reviewed the article, In general the work is supported by the equal contribution of the authors. Both authors read and approved the final manuscript.

\section{Acknowledgements}

We thank Mrs Fadwa AL-Khulaifi for her help in references collecting and also to Dr Vijaya Ravinayagam for her valuable comments and revision for the figures and manuscript.

Received: 5 January 2013 Accepted: 3 April 2013

Published: 1 May 2013

\section{References}

1. Hahn P, Novak M: Development of brown and white adipose tissue. J Lipid Res 1975, 16:79-91.

2. Kershaw EE, Flier JS: Adipose tissue as an endocrine organ. J Clin Endocrinol Metab 2004, 89:2548-2556.

3. Wiecek A, Kokot F, Chudek J, Adamczak M: The adipose tissue-a novel endocrine organ of interest to the nephrologist. Nephrol Dial Transplant 2002, 17:191-195.

4. Matsuzawa Y: Adiponectin: a key player in obesity related disorders. Curr Pharm Des 2010, 16:1896-1901.

5. Singla P, Bardoloi A, Parkash AA: Metabolic effects of obesity: A review. World J Diabetes 2010, 1:76-88.

6. Genc H, Dogru T, Tapan S, Kara M, Ercin CN, Aslan F, Kantarcioglu M, Karslioglu Y, Sertoglu E, Erbil MK, Bagci S: Circulating vaspin and its relationship with insulin sensitivity, adiponectin, and liver histology in subjects with non-alcoholic steatohepatitis. Scand J Gastroenterol 2011, 46:1355-1361.

7. Yamawaki H, Kuramoto J, Kameshima S, Usui T, Okada M, Hara Y: Omentin, a novel adipocytokine inhibits TNF-induced vascular inflammation in human endothelial cells. Biochem Biophys Res Commun 2011, 408:339-343. 
8. Gualillo O, Gonzalez-Juanatey JR, Lago F: The emerging role of adipokines as mediators of cardiovascular function: physiologic and clinical perspectives. Trends Cardiovasc Med 2007, 17:275-283.

9. Galic S, Oakhill JS, Steinberg GR: Adipose tissue as an endocrine organ. Mol Cell Endocrinol 2010, 316:129-139.

10. Deepa SS, Dong LQ: APPL1: role in adiponectin signaling and beyond. Am J Physiol Endocrinol Metab 2009, 296:E22-36.

11. Tilg $\mathrm{H}$, Moschen AR: Adipocytokines: mediators linking adipose tissue, inflammation and immunity. Nat Rev Immunol 2006, 6:772-783.

12. Pandzic Jaksic V: Adipocytokines as mediators of metabolic role of adipose tissue. Acta Med Croatica 2010, 64:253-262.

13. Tilg H, Moschen AR: Role of adiponectin and PBEF/visfatin as regulators of inflammation: involvement in obesity-associated diseases. Clin Sci (Lond) 2008, 114:275-288.

14. Williams KW, Scott MM, Elmquist JK: From observation to experimentation: leptin action in the mediobasal hypothalamus. Am J Clin Nutr 2009, 89:985S-990S.

15. Bluher S, Mantzoros CS: Leptin in humans: lessons from translational research. Am J Clin Nutr 2009, 89:991S-997S

16. Van Harmelen V, Reynisdottir S, Eriksson P, Thorne A, Hoffstedt J, Lonnqvist F, Arner P: Leptin secretion from subcutaneous and visceral adipose tissue in women. Diabetes 1998, 47:913-917.

17. Bado A, Levasseur S, Attoub S, Kermorgant S, Laigneau JP, Bortoluzzi MN, Moizo L, Lehy T, Guerre-Millo M, Le Marchand-Brustel Y, Lewin MJ: The stomach is a source of leptin. Nature 1998, 394:790-793.

18. Howard JM, Pidgeon GP, Reynolds JV: Leptin and gastro-intestinal malignancies. Obes Rev 2010, 11:863-874.

19. Ahima RS, Prabakaran D, Mantzoros C, Qu D, Lowell B, Maratos-Flier E, Flier JS: Role of leptin in the neuroendocrine response to fasting. Nature 1996, 382:250-252.

20. Flier JS: Clinical review 94: What's in a name? In search of leptin's physiologic role. J Clin Endocrinol Metab 1998, 83:1407-1413.

21. Koerner A, Kratzsch J, Kiess W: Adipocytokines: leptin-the classical, resistin-the controversical, adiponectin-the promising, and more to come. Best Pract Res Clin Endocrinol Metab 2005, 19:525-546.

22. Konturek PC, Konturek JW, Czesnikiewicz-Guzik M, Brzozowski T, Sito E, Konturek SJ: Neuro-hormonal control of food intake: basic mechanisms and clinical implications. J Physiol Pharmacol 2005, 56(Suppl 6):5-25.

23. Hegyi K, Fulop K, Kovacs K, Toth S, Falus A: Leptin-induced signal transduction pathways. Cell Biol Int 2004, 28:159-169.

24. Uotani S, Bjorbaek C, Tornoe J, Flier JS: Functional properties of leptin receptor isoforms: internalization and degradation of leptin and ligand-induced receptor downregulation. Diabetes 1999, 48:279-286.

25. Myers MG, Cowley MA, Munzberg H: Mechanisms of leptin action and leptin resistance. Annu Rev Physiol 2008, 70:537-556.

26. Konopleva M, Mikhail A, Estrov Z, Zhao S, Harris D, Sanchez-Williams G, Kornblau SM, Dong J, Kliche KO, Jiang S, Snodgrass HR, Estey EH, Andreeff $M$ : Expression and function of leptin receptor isoforms in myeloid leukemia and myelodysplastic syndromes: proliferative and antiapoptotic activities. Blood 1999, 93:1668-1676.

27. Tsuchiya $T$, Shimizu H, Horie T, Mori M: Expression of leptin receptor in lung: leptin as a growth factor. Eur J Pharmacol 1999, 365:273-279.

28. Artwohl M, Roden M, Holzenbein T, Freudenthaler A, Waldhausl W, Baumgartner-Parzer SM: Modulation by leptin of proliferation and apoptosis in vascular endothelial cells. Int J Obes Relat Metab Disord 2002, 26:577-580.

29. Koda M, Kanczuga-Koda L, Sulkowska M, Surmacz E, Sulkowski S: Relationships between hypoxia markers and the leptin system, estrogen receptors in human primary and metastatic breast cancer: effects of preoperative chemotherapy. BMC Cancer 2010, 10:320

30. Holcomb IN, Kabakoff RC, Chan B, Baker TW, Gurney A, Henzel W, Nelson C, Lowman HB, Wright BD, Skelton NJ, Frantz GD, Tumas DB, Peale FV Jr, Shelton DL, Hébert CC: FIZZ1, a novel cysteine-rich secreted protein associated with pulmonary inflammation, defines a new gene family. EMBO J 2000, 19:4046-4055.

31. Steppan CM, Bailey ST, Bhat S, Brown EJ, Banerjee RR, Wright CM, Patel HR, Ahima RS, Lazar MA: The hormone resistin links obesity to diabetes. Nature 2001, 409:307-312.

32. Rajala MW, Lin $Y$, Ranalletta M, Yang XM, Qian H, Gingerich $R$, Barzilai N, Scherer PE: Cell type-specific expression and coregulation of murine resistin and resistin-like molecule-alpha in adipose tissue. Mol Endocrinol 2002, 16:1920-1930.
33. Chumakov AM, Kubota T, Walter S, Koeffler HP: Identification of murine and human XCP1 genes as C/EBP-epsilon-dependent members of FIZZ/Resistin gene family. Oncogene 2004, 23:3414-3425.

34. Patel L, Buckels AC, Kinghorn IJ, Murdock PR, Holbrook JD, Plumpton C, Macphee CH, Smith SA: Resistin is expressed in human macrophages and directly regulated by PPAR gamma activators. Biochem Biophys Res Commun 2003, 300:472-476.

35. Nohira T, Nagao K, Kameyama K, Nakai H, Fukumine N, Okabe K, Kitano S, Hisatomi $\mathrm{H}$ : Identification of an alternative splicing transcript for the resistin gene and distribution of its $\mathrm{mRNA}$ in human tissue. Eur J Endocrinol 2004, 151:151-154.

36. Lazar MA: Resistin- and Obesity-associated metabolic diseases. Horm Metab Res 2007, 39:710-716.

37. Kusminski CM, McTernan PG, Kumar S: Role of resistin in obesity, insulin resistance and Type II diabetes. Clin Sci (Lond) 2005, 109:243-256.

38. Fukuhara A, Matsuda M, Nishizawa M, Segawa K, Tanaka M, Kishimoto K, Matsuki Y, Murakami M, Ichisaka T, Murakami H, Watanabe E, Takagi T, Akiyoshi M, Ohtsubo T, Kihara S, Yamashita S, Makishima M, Funahashi T, Yamanaka S, Hiramatsu R, Matsuzawa Y, Shimomura I: Visfatin: a protein secreted by visceral fat that mimics the effects of insulin. Science 2005, 307:426-430.

39. Rongvaux A, Shea RJ, Mulks MH, Gigot D, Urbain J, Leo O, Andris F: Pre-B-cell colony-enhancing factor, whose expression is up-regulated in activated lymphocytes, is a nicotinamide phosphoribosyltransferase, a cytosolic enzyme involved in NAD biosynthesis. Eur J Immunol 2002, 32:3225-3234.

40. Ray A: Adipokine leptin in obesity-related pathology of breast cancer. J Biosci 2012, 37:289-294

41. Chen H, Charlat O, Tartaglia LA, Woolf EA, Weng X, Ellis SJ, Lakey ND, Culpepper J, Moore KJ, Breitbart RE, Duyk GM, Tepper RI, Morgenstern JP: Evidence that the diabetes gene encodes the leptin receptor: identification of a mutation in the leptin receptor gene in db/db mice. Cell 1996, 84:491-495.

42. Malik KF, Young WS 3rd: Localization of binding sites in the central nervous system for leptin (OB protein) in normal, obese (ob/ob), and diabetic (db/db) C57BL/6J mice. Endocrinology 1996, 137:1497-1500.

43. Zhang Y, Proenca R, Maffei M, Barone M, Leopold L, Friedman JM: Positional cloning of the mouse obese gene and its human homologue. Nature 1994, 372:425-432.

44. Frederich RC, Hamann A, Anderson S, Lollmann B, Lowell BB, Flier JS: Leptin levels reflect body lipid content in mice: evidence for diet-induced resistance to leptin action. Nat Med 1995, 1:1311-1314.

45. Segal KR, Landt M, Klein S: Relationship between insulin sensitivity and plasma leptin concentration in lean and obese men. Diabetes 1996, 45:988-991.

46. Van Heek M, Compton DS, France CF, Tedesco RP, Fawzi AB, Graziano MP, Sybertz EJ, Strader CD, Davis HR Jr: Diet-induced obese mice develop peripheral, but not central, resistance to leptin. J Clin Invest 1997, 99:385-390

47. Kobayashi S, Kabuto T, Doki Y, Yamada T, Miyashiro I, Murata K, Hiratsuka M, Kameyama M, Ohigashi H, Sasaki Y, Ishikawa O, Imaoka S: Synchronous esophageal and renal cell carcinoma. Dis Esophagus 2000, 13:305-310.

48. Tartaglia LA: The leptin receptor. J Biol Chem 1997, 272:6093-6096.

49. Bjorbaek C, Kahn BB: Leptin signaling in the central nervous system and the periphery. Recent Prog Horm Res 2004, 59:305-331.

50. Sousa M, Bras-Silva C, Leite-Moreira A: The role of leptin in the regulation of energy balance. Acta Med Port 2009, 22:291-298. Portuguese.

51. Coppola A, Marfella R, Coppola L, Tagliamonte E, Fontana D, Liguori E, Cirillo T, Cafiero M, Natale S, Astarita C: Effect of weight loss on coronary circulation and adiponectin levels in obese women. Int J Cardio/ 2009, 134:414-416.

52. Bates SH, Stearns WH, Dundon TA, Schubert M, Tso AW, Wang Y, Banks AS, Lavery HJ, Haq AK, Maratos-Flier E, Neel BG, Schwartz MW, Myers MG Jr: STAT3 signalling is required for leptin regulation of energy balance but not reproduction. Nature 2003, 421:856-859.

53. Munzberg H, Huo L, Nillni EA, Hollenberg AN, Bjorbaek C: Role of signal transducer and activator of transcription 3 in regulation of hypothalamic proopiomelanocortin gene expression by leptin. Endocrinology 2003, 144:2121-2131.

54. Mori H, Hanada R, Hanada T, Aki D, Mashima R, Nishinakamura H, Torisu T, Chien KR, Yasukawa H, Yoshimura A: Socs3 deficiency in the brain elevates leptin sensitivity and confers resistance to diet-induced obesity. Nat Med 2004, 10:739-743.

55. Ueki K, Kondo T, Kahn CR: Suppressor of cytokine signaling 1 (SOCS-1) and SOCS-3 cause insulin resistance through inhibition of tyrosine phosphorylation of insulin receptor substrate proteins by discrete mechanisms. Mol Cell Biol 2004, 24:5434-5446. 
56. Metlakunta AS, Sahu M, Yasukawa H, Dhillon SS, Belsham DD, Yoshimura A, Sahu A: Neuronal suppressor of cytokine signaling-3 deficiency enhances hypothalamic leptin-dependent phosphatidylinositol 3-kinase signaling. Am J Physiol Regul Integr Comp Physiol 2011, 300:R1185-1193.

57. Sahu A: Intracellular leptin-signaling pathways in hypothalamic neurons: the emerging role of phosphatidylinositol-3 kinase-phosphodiesterase-3BCAMP pathway. Neuroendocrinology 2011, 93:201-210.

58. Chen J: The Src/PI3K/Akt pathway may play a key role in the production of IL-17 in obesity. J Leukoc Biol 2010, 87:355. author reply 357.

59. Montagnani M, Golovchenko I, Kim I, Koh GY, Goalstone ML, Mundhekar AN, Johansen M, Kucik DF, Quon MJ, Draznin B: Inhibition of phosphatidylinositol 3-kinase enhances mitogenic actions of insulin in endothelial cells. J Biol Chem 2002, 277:1794-1799.

60. Suganami E, Takagi H, Ohashi H, Suzuma K, Suzuma I, Oh H, Watanabe D, Ojima T, Suganami T, Fujio Y, Nakao K, Ogawa Y, Yoshimura N: Leptin stimulates ischemia-induced retinal neovascularization: possible role of vascular endothelial growth factor expressed in retinal endothelial cells. Diabetes 2004, 53:2443-2448.

61. Hausman GJ, Richardson RL: Adipose tissue angiogenesis. J Anim Sci 2004, 82:925-934.

62. Buettner C, Pocai A, Muse ED, Etgen AM, Myers MG Jr, Rossetti L: Critical role of STAT3 in leptin's metabolic actions. Cell Metab 2006, 4:49-60.

63. Cohen SE, Kokkotou E, Biddinger SB, Kondo T, Gebhardt R, Kratzsch J, Mantzoros CS, Kahn CR: High circulating leptin receptors with normal leptin sensitivity in liver-specific insulin receptor knock-out (LIRKO) mice. J Biol Chem 2007, 282:23672-23678.

64. Mojiminiyi OA, Abdella NA: Associations of resistin with inflammation and insulin resistance in patients with type 2 diabetes mellitus. Scand J Clin Lab Invest 2007, 67:215-225.

65. Oliver P, Pico C, Serra F, Palou A: Resistin expression in different adipose tissue depots during rat development. Mol Cell Biochem 2003, 252:397-400.

66. Degawa-Yamauchi M, Bovenkerk JE, Juliar BE, Watson W, Kerr K, Jones R, Zhu Q, Considine RV: Serum resistin (FIZZ3) protein is increased in obese humans. J Clin Endocrinol Metab 2003, 88:5452-5455.

67. Ort T, Arjona AA, MacDougall JR, Nelson PJ, Rothenberg ME, Wu F, Eisen A, Halvorsen YD: Recombinant human FIZZ3/resistin stimulates lipolysis in cultured human adipocytes, mouse adipose explants, and normal mice. Endocrinology 2005, 146:2200-2209.

68. Mu H, Ohashi R, Yan S, Chai H, Yang H, Lin P, Yao Q, Chen C: Adipokine resistin promotes in vitro angiogenesis of human endothelial cells. Cardiovasc Res 2006, 70:146-157.

69. Solinas G, Karin M: JNK1 and IKKbeta: molecular links between obesity and metabolic dysfunction. FASEB J 2010, 24:2596-2611.

70. Ukkola O: Resistin - a mediator of obesity-associated insulin resistance or an innocent bystander? Eur J Endocrinol 2002, 147:571-574.

71. Kochan Z, Karbowska J: Resistine-a new hormone secreted by adipose tissue (adipose tissue in insulin resistance). Przegl Lek 2003, 60:40-42.

72. Morash BA, Willkinson D, Ur E, Wilkinson M: Resistin expression and regulation in mouse pituitary. FEBS Lett 2002, 526:26-30.

73. Brunetti L, Orlando G, Recinella L, Michelotto B, Ferrante C, Vacca M: Resistin, but not adiponectin, inhibits dopamine and norepinephrine release in the hypothalamus. Eur J Pharmacol 2004, 493:41-44.

74. Tovar S, Nogueiras R, Tung LY, Castaneda TR, Vazquez MJ, Morris A, Williams LM, Dickson SL, Dieguez C: Central administration of resistin promotes short-term satiety in rats. Eur J Endocrinol 2005, 153:R1-5.

75. Berndt J, Kloting N, Kralisch S, Kovacs P, Fasshauer M, Schon MR, Stumvoll M, Bluher M: Plasma visfatin concentrations and fat depot-specific mRNA expression in humans. Diabetes 2005, 54:2911-2916.

76. Pagano C, Pilon C, Olivieri M, Mason P, Fabris R, Serra R, Milan G, Rossato M, Federspil G, Vettor R: Reduced plasma visfatin/pre-B cell colonyenhancing factor in obesity is not related to insulin resistance in humans. J Clin Endocrinol Metab 2006, 91:3165-3170.

77. Haider DG, Holzer G, Schaller G, Weghuber D, Widhalm K, Wagner O Kapiotis S, Wolzt M: The adipokine visfatin is markedly elevated in obese children. J Pediatr Gastroenterol Nutr 2006, 43:548-549.

78. Zahorska-Markiewicz B, Olszanecka-Glinianowicz M, Janowska J, Kocelak P, Semik-Grabarczyk E, Holecki M, Dabrowski P, Skorupa A: Serum concentration of visfatin in obese women. Metabolism 2007, 56:1131-1134.

79. Jin H, Jiang B, Tang J, Lu W, Wang W, Zhou L, Shang W, Li F, Ma Q, Yang Y, Chen M: Serum visfatin concentrations in obese adolescents and its correlation with age and high-density lipoprotein cholesterol. Diabetes Res Clin Pract 2008, 79:412-418.

80. Sun C, Zhang F, Ge X, Yan T, Chen X, Shi X, Zhai Q: SIRT1 improves insulin sensitivity under insulin-resistant conditions by repressing PTP1B. Cell Metab 2007, 6:307-319.

81. Revollo JR, Korner A, Mills KF, Satoh A, Wang T, Garten A, Dasgupta B, Sasaki Y, Wolberger C, Townsend RR, Milbrandt J, Kiess W, Imai S: Nampt/PBEF/ Visfatin regulates insulin secretion in beta cells as a systemic NAD biosynthetic enzyme. Cell Metab 2007, 6:363-375.

82. Mercader J, Granados N, Caimari A, Oliver P, Bonet ML, Palou A: Retinol-binding protein 4 and nicotinamide phosphoribosyltransferase/visfatin in rat obesity models. Horm Metab Res 2008, 40:467-472.

83. Kloting N, Kloting I: Visfatin: gene expression in isolated adipocytes and sequence analysis in obese WOKW rats compared with lean control rats. Biochem Biophys Res Commun 2005, 332:1070-1072.

84. Adya R, Tan BK, Punn A, Chen J, Randeva HS: Visfatin induces human endothelial VEGF and MMP-2/9 production via MAPK and PI3K/Akt signalling pathways: novel insights into visfatin-induced angiogenesis. Cardiovasc Res 2008, 78:356-365.

85. Ferrante AW Jr, Thearle M, Liao T, Leibel RL: Effects of leptin deficiency and short-term repletion on hepatic gene expression in genetically obese mice. Diabetes 2001, 50:2268-2278.

86. Martin SS, Qasim A, Reilly MP: Leptin resistance: a possible interface of inflammation and metabolism in obesity-related cardiovascular disease. J Am Coll Cardiol 2008, 52:1201-1210.

87. Kulkarni RN, Wang ZL, Wang RM, Hurley JD, Smith DM, Ghatei MA, Withers DJ, Gardiner JV, Bailey CJ, Bloom SR: Leptin rapidly suppresses insulin release from insulinoma cells, rat and human islets and, in vivo, in mice. J Clin Invest 1997, 100:2729-2736.

88. Spiegelman BM, Flier JS: Obesity and the regulation of energy balance. Cell 2001, 104:531-543.

89. Tucholski K, Otto-Buczkowska E: The role of leptin in the regulation of carbohydrate metabolism. Endokrynol Pol 2011, 62:258-262.

90. Morton GJ: Hypothalamic leptin regulation of energy homeostasis and glucose metabolism. J Physiol 2007, 583(Pt 2):437-443.

91. Hillebrand JJ, Geary N: Do leptin and insulin signal adiposity? Forum Nutr 2010, 63:111-122.

92. Davis JF, Choi DL, Benoit SC: Insulin, leptin and reward. Trends Endocrinol Metab 2010, 21:68-74

93. Levi J, Huynh FK, Denroche HC, Neumann UH, Glavas MM, Covey SD, Kieffer $\mathrm{TJ}$ : Hepatic leptin signalling and subdiaphragmatic vagal efferents are not required for leptin-induced increases of plasma IGF binding protein-2 (IGFBP-2) in ob/ob mice. Diabetologia 2012, 55:752-762.

94. Schultze SM, Hemmings BA, Niessen M, Tschopp O: PI3K/AKT, MAPK and AMPK signalling: protein kinases in glucose homeostasis. Expert Rev Mol Med 2012, 14:e1.

95. Kitamura T, Feng Y, Kitamura YI, Chua SC Jr, Xu AW, Barsh GS, Rossetti L, Accili D: Forkhead protein FoxO1 mediates Agrp-dependent effects of leptin on food intake. Nat Med 2006, 12:534-540.

96. Kohn AD, Barthel A, Kovacina KS, Boge A, Wallach B, Summers SA, Birnbaum MJ, Scott PH, Lawrence JC Jr, Roth RA: Construction and characterization of a conditionally active version of the serine/threonine kinase Akt. J Biol Chem 1998, 273:11937-11943.

97. Kohn AD, Summers SA, Birnbaum MJ, Roth RA: Expression of a constitutively active Akt Ser/Thr kinase in 3T3-L1 adipocytes stimulates glucose uptake and glucose transporter 4 translocation. J Biol Chem 1996, 271:31372-31378.

98. Huang S, Czech MP: The GLUT4 glucose transporter. Cell Metab 2007, 5:237-252.

99. Wallberg-Henriksson H, Zierath JR: GLUT4: a key player regulating glucose homeostasis? Insights from transgenic and knockout mice (review). Mol Membr Biol 2001, 18:205-211.

100. Leturque A, Brot-Laroche E, Le Gall M, Stolarczyk E, Tobin V: The role of GLUT2 in dietary sugar handling. J Physiol Biochem 2005, 61:529-537.

101. Zhao FQ, Keating AF: Functional properties and genomics of glucose transporters. Curr Genomics 2007, 8:113-128.

102. Benomar Y, Naour N, Aubourg A, Bailleux V, Gertler A, Djiane J, Guerre-Millo M, Taouis M: Insulin and leptin induce Glut4 plasma membrane translocation and glucose uptake in a human neuronal cell line by a phosphatidylinositol 3-kinase- dependent mechanism. Endocrinology 2006, 147:2550-2556.

103. Sainz N, Rodriguez A, Catalan V, Becerril S, Ramirez B, Lancha A, Burgos-Ramos E, Gomez-Ambrosi J, Fruhbeck G: Leptin reduces the expression and 
increases the phosphorylation of the negative regulators of GLUT4 traffic TBC1D1 and TBC1D4 in muscle of ob/ob mice. PLoS One 2012, 7:e29389.

104. Bruss MD, Arias EB, Lienhard GE, Cartee GD: Increased phosphorylation of Akt substrate of $160 \mathrm{kDa}$ (AS160) in rat skeletal muscle in response to insulin or contractile activity. Diabetes 2005, 54:41-50.

105. Lin Y, Sun Z: Current views on type 2 diabetes. J Endocrinol 2010, 204:1-11.

106. Martinez A, Castro A, Dorronsoro I, Alonso M: Glycogen synthase kinase 3 (GSK-3) inhibitors as new promising drugs for diabetes, neurodegeneration, cancer, and inflammation. Med Res Rev 2002, 22:373-384.

107. Clodfelder-Miller B, De Sarno P, Zmijewska AA, Song L, Jope RS: Physiological and pathological changes in glucose regulate brain Akt and glycogen synthase kinase-3. J Biol Chem 2005, 280:39723-39731.

108. Nikoulina SE, Ciaraldi TP, Mudaliar S, Mohideen P, Carter L, Henry RR: Potential role of glycogen synthase kinase- 3 in skeletal muscle insulin resistance of type 2 diabetes. Diabetes 2000, 49:263-271.

109. Weston CR, Davis RJ: Signal transduction: signaling specificity- a complex affair. Science 2001, 292:2439-2440.

110. Hill JW, Williams KW, Ye C, Luo J, Balthasar N, Coppari R, Cowley MA, Cantley LC, Lowell BB, Elmquist JK: Acute effects of leptin require PI3K signaling in hypothalamic proopiomelanocortin neurons in mice. J Clin Invest 2008, 118:1796-1805.

111. Namkoong C, Kim MS, Jang PG, Han SM, Park HS, Koh EH, Lee WJ, Kim JY, Park IS, Park JY, Lee KU: Enhanced hypothalamic AMP-activated protein kinase activity contributes to hyperphagia in diabetic rats. Diabetes 2005, 54:63-68.

112. Goren I, Muller E, Pfeilschifter J, Frank S: Severely impaired insulin signaling in chronic wounds of diabetic ob/ob mice: a potential role of tumor necrosis factor-alpha. Am J Pathol 2006, 168:765-777.

113. Al-Harithy RN, Al-Ghamdi S: Serum resistin, adiposity and insulin resistance in Saudi women with type 2 diabetes mellitus. Ann Saudi Med 2005, 25:283-287.

114. Yannakoulia M, Yiannakouris N, Bluher S, Matalas AL, Klimis-Zacas D, Mantzoros CS: Body fat mass and macronutrient intake in relation to circulating soluble leptin receptor, free leptin index, adiponectin, and resistin concentrations in healthy humans. J Clin Endocrinol Metab 2003, 88:1730-1736.

115. Silha JV, Krsek M, Skrha JV, Sucharda P, Nyomba BL, Murphy LJ: Plasma resistin, adiponectin and leptin levels in lean and obese subjects: correlations with insulin resistance. Eur J Endocrinol 2003, 149:331-335.

116. Janke J, Engeli S, Gorzelniak K, Luft FC, Sharma AM: Resistin gene expression in human adipocytes is not related to insulin resistance. Obes Res 2002, 10:1-5

117. McTernan PG, McTernan CL, Chetty R, Jenner K, Fisher FM, Lauer MN, Crocker J, Barnett AH, Kumar S: Increased resistin gene and protein expression in human abdominal adipose tissue. $J$ Clin Endocrinol Metab 2002, 87:2407.

118. Smith SR, Bai F, Charbonneau C, Janderova L, Argyropoulos G: A promoter genotype and oxidative stress potentially link resistin to human insulin resistance. Diabetes 2003, 52:1611-1618.

119. Walcher D, Hess K, Berger R, Aleksic M, Heinz P, Bach H, Durst R, Hausauer A, Hombach V, Marx N: Resistin: a newly identified chemokine for human CD4-positive lymphocytes. Cardiovasc Res 2010, 85:167-174.

120. Banerjee RR, Rangwala SM, Shapiro JS, Rich AS, Rhoades B, Qi Y, Wang J, Rajala MW, Pocai A, Scherer PE, Steppan CM, Ahima RS, Obici S, Rossetti L, Lazar MA: Regulation of fasted blood glucose by resistin. Science 2004, 303:1195-1198.

121. Steppan CM, Wang J, Whiteman EL, Birnbaum MJ, Lazar MA: Activation of SOCS-3 by resistin. Mol Cell Biol 2005, 25:1569-1575.

122. Shi H, Tzameli I, Bjorbaek C, Flier JS: Suppressor of cytokine signaling 3 is a physiological regulator of adipocyte insulin signaling. J Biol Chem 2004, 279:34733-34740.

123. Qi Y, Nie Z, Lee YS, Singhal NS, Scherer PE, Lazar MA, Ahima RS: Loss of resistin improves glucose homeostasis in leptin deficiency. Diabetes 2006, 55:3083-3090.

124. Stofkova A: Resistin and visfatin: regulators of insulin sensitivity, inflammation and immunity. Endocr Regul 2010, 44:25-36.

125. Makimura $\mathrm{H}$, Mizuno TM, Bergen $\mathrm{H}$, Mobbs CV: Adiponectin is stimulated by adrenalectomy in ob/ob mice and is highly correlated with resistin mRNA. Am J Physiol Endocrinol Metab 2002, 283:E1266-1271.

126. Bauer S, Neumeier M, Wanninger J, Walter R, Kopp A, Bala M, Schaffler A, Buechler C: Systemic resistin is increased in type 2 diabetic patients treated with loop diuretics. J Diabetes Complications 2011, 25:377-381.
127. McGee KC, Harte AL, da Silva NF, Al-Daghri N, Creely SJ, Kusminski CM, Tripathi G, Levick PL, Khanolkar M, Evans M, Chittari MV, Patel V, Kumar S, McTernan PG: Visfatin is regulated by rosiglitazone in type 2 diabetes mellitus and influenced by NFkappaB and JNK in human abdominal subcutaneous adipocytes. PLoS One 2011, 6:e20287.

128. Grunfeld C: Leptin and the immunosuppression of malnutrition. J Clin Endocrinol Metab 2002, 87:3038-3039.

129. Bruno A, Conus S, Schmid I, Simon HU: Apoptotic pathways are inhibited by leptin receptor activation in neutrophils. J Immunol 2005, 174:8090-8096.

130. Otero M, Lago R, Gomez R, Dieguez C, Lago F, Gomez-Reino J, Gualillo O: Towards a pro-inflammatory and immunomodulatory emerging role of leptin. Rheumatology (Oxford) 2006, 45:944-950.

131. Stofkova A: Leptin and adiponectin: from energy and metabolic dysbalance to inflammation and autoimmunity. Endocr Regul 2009, 43:157-168.

132. Sanchez-Margalet V, Martin-Romero C, Santos-Alvarez J, Goberna R, Najib S, Gonzalez-Yanes C: Role of leptin as an immunomodulator of blood mononuclear cells: mechanisms of action. Clin Exp Immunol 2003, 133:11-19.

133. Haas P, Straub RH, Bedoui S, Nave H: Peripheral but not central leptin treatment increases numbers of circulating NK cells, granulocytes and specific monocyte subpopulations in non-endotoxaemic lean and obese LEW-rats. Regul Pept 2008, 151:26-34.

134. Lo CK, Lam QL, Yang M, Ko KH, Sun L, Ma R, Wang S, Xu H, Tam S, Wu CY, Zheng BJ, Lu L: Leptin signaling protects NK cells from apoptosis during development in mouse bone marrow. Cell Mol Immunol 2009, 6:353-360.

135. Li Z, Lin H, Yang S, Diehl AM: Murine leptin deficiency alters Kupffer cell production of cytokines that regulate the innate immune system. Gastroenterology 2002, 123:1304-1310.

136. Sennello JA, Fayad R, Morris AM, Eckel RH, Asilmaz E, Montez J, Friedman JM, Dinarello CA, Fantuzzi G: Regulation of T cell-mediated hepatic inflammation by adiponectin and leptin. Endocrinology 2005, 146:2157-2164.

137. Gruen ML, Hao M, Piston DW, Hasty AH: Leptin requires canonical migratory signaling pathways for induction of monocyte and macrophage chemotaxis. Am J Physiol Cell Physiol 2007, 293:C1481-1488.

138. Napoleone E, Dis A, Amore C, Baccante G, di Febbo C, Porreca E, de Gaetano G, Donati MB, Lorenzet R: Leptin induces tissue factor expression in human peripheral blood mononuclear cells: a possible link between obesity and cardiovascular risk? J Thromb Haemost 2007, 5:1462-1468.

139. Kim SY, Lim JH, Choi SW, Kim M, Kim ST, Kim MS, Cho YS, Chun E, Lee KY: Preferential effects of leptin on CD4 T cells in central and peripheral immune system are critically linked to the expression of leptin receptor. Biochem Biophys Res Commun 2010, 394:562-568.

140. Martin-Romero C, Santos-Alvarez J, Goberna R, Sanchez-Margalet V: Human leptin enhances activation and proliferation of human circulating $T$ lymphocytes. Cell Immunol 2000, 199:15-24.

141. Lord GM, Matarese G, Howard JK, Bloom SR, Lechler Rl: Leptin inhibits the anti-CD3-driven proliferation of peripheral blood T cells but enhances the production of proinflammatory cytokines. J Leukoc Biol 2002, 72:330-338.

142. Caspar-Bauguil S, Cousin B, Bour S, Casteilla L, Penicaud L, Carpene C: Adipose tissue lymphocytes: types and roles. J Physiol Biochem 2009, 65:423-436.

143. Leivo-Korpela S, Lehtimaki L, Vuolteenaho K, Nieminen R, Kankaanranta H, Saarelainen S, Moilanen E: Adipokine resistin predicts anti-inflammatory effect of glucocorticoids in asthma. J Inflamm (Lond) 2011, 8:12.

144. Kaser S, Kaser A, Sandhofer A, Ebenbichler CF, Tilg H, Patsch JR: Resistin messenger-RNA expression is increased by proinflammatory cytokines in vitro. Biochem Biophys Res Commun 2003, 309:286-290.

145. Beier Jl, Guo L, von Montfort C, Kaiser JP, Joshi-Barve S, Arteel GE: New role of resistin in lipopolysaccharide-induced liver damage in mice. J Pharmacol Exp Ther 2008, 325:801-808.

146. Konrad A, Lehrke M, Schachinger V, Seibold F, Stark R, Ochsenkuhn T, Parhofer KG, Goke B, Broedl UC: Resistin is an inflammatory marker of inflammatory bowel disease in humans. Eur J Gastroenterol Hepatol 2007, 19:1070-1074.

147. Adrych K, Smoczynski M, Stelmanska E, Korczynska J, Goyke E, Swierczynski J: Serum adiponectin and leptin concentrations in patients with chronic pancreatitis of alcoholic and nonalcoholic origin. Pancreas 2008, 36:120-124.

148. Almehed K, d'Elia HF, Bokarewa M, Carlsten H: Role of resistin as a marker of inflammation in systemic lupus erythematosus. Arthritis Res Ther 2008, 10:R15. 
149. Samal B, Sun Y, Stearns G, Xie C, Suggs S, McNiece I: Cloning and characterization of the CDNA encoding a novel human pre-B-cell colony-enhancing factor. Mol Cell Biol 1994, 14:1431-1437.

150. Moschen AR, Kaser A, Enrich B, Mosheimer B, Theurl M, Niederegger H, Tilg $\mathrm{H}$ : Visfatin, an adipocytokine with proinflammatory and immunomodulating properties. J Immunol 2007, 178:1748-1758.

151. Jia SH, Li Y, Parodo J, Kapus A, Fan L, Rotstein OD, Marshall JC: Pre-B cell colony-enhancing factor inhibits neutrophil apoptosis in experimental inflammation and clinical sepsis. J Clin Invest 2004, 113:1318-1327.

152. Lago F, Dieguez C, Gomez-Reino J, Gualillo O: Adipokines as emerging mediators of immune response and inflammation. Nat Clin Pract Rheumatol 2007, 3:716-724.

153. Gomez R, Conde J, Scotece M, Gomez-Reino JJ, Lago F, Gualillo O: What's new in our understanding of the role of adipokines in rheumatic diseases? Nat Rev Rheumatol 2011, 7:528-536.

doi:10.1186/2047-783X-18-12

Cite this article as: AL-Suhaimi and Shehzad: Leptin, resistin and visfatin: the missing link between endocrine metabolic disorders and immunity. European Journal of Medical Research 2013 18:12.

\section{Submit your next manuscript to BioMed Central and take full advantage of:}

- Convenient online submission

- Thorough peer review

- No space constraints or color figure charges

- Immediate publication on acceptance

- Inclusion in PubMed, CAS, Scopus and Google Scholar

- Research which is freely available for redistribution 